\title{
Entrepreneurial orientation: A Remedy for Receding Productivity of Small and Medium scale Enterprise A Nigeria perspective
}

\author{
Omolomo Odunayo Tobora \\ Universiti of Malaysia, Sawarak Faculty of Economics and Business, 94300 Kota Samarahan, \\ Sawarak, Malaysia \\ Email address: odunayophd@yahoo.ca
}

\begin{abstract}
Nigeria is experiencing immense structural changes which are affecting the economy. Entrepreneurial orientation(EO) is a vital force in the economy of any nation because of the strategic role it plays in the achievement of productivity. The aim of this paper is to provide more insight into EO as a remedy for productivity for small and medium scale enterprises in Nigeria by providing in-depth knowledge of the nature and behavior of an entrepreneur and its dimensions toward risk taking, proactivness and the aggressivess. How all these can lead to entrepreneurship through(EO) also formed the vanguard of modern enterprises. The creation of a country's wealth and dynamism depends upon the Entrepreneurial orientation of its firms and this, in turn, relies fundamentally on the capabilities of its entrepreneurs and managers.
\end{abstract}

Keywords: Productivity; Entrepreneurial Orientation; Small and Medium Enterprises; Entrepreneurship

\section{INTRODUCTION}

One of the main challenges in defining a cross-country SME is the absence of a universal definition of what constitutes an SME. A number of efforts aim to streamline and harmonize SME definitions (OECD, 2004), although the heterogeneity of SMEs themselves and the nature of the economy, they operate in might mean that establishing a global definition is not feasible.

Oshagbemi (1982) highlights some major criteria used in the definitions of Small, Medium Scale Enterprises (SMEs) to include:

i. Number of employees.

ii. Financial strength

iii. Sales value

iv. Initial capital outlay

v. Relative size

vi. Independent ownership

vii. The type of industry

Small and medium scale Enterprises (SMEs) are as much an important economic catalyst in industrialised countries as they are in the developing world. In many developed coun- 
tries, more than $98 \%$ of all enterprises belong to the SME sector. $80 \%$ of the total industrial labour force in Japan, $50 \%$ in Germany and $46 \%$ in the USA are employed in smaller firms. In USA, small business contributes nearly 39\% to the national income. Udechukwu (2009) posit that, contrary to the general impression, Figures in many developed countries are even higher. In the past three decades, Nigeria as developing countries has observed a progressive business ownership, particularly in micro and small businesses in the informal sector. Their involvement in business ownership has not only affected household economies and division of labour but also bears significant impact on the way Nigerian do business. Small and Medium Enterprises (SMEs) have been the backbone of economic growth of an economy in driving industrial development (Hoq, Ha, \& Said, 2009; Mohd Aris N, 2006; Mohd Asri \& Mohd Isa, 2000) According to Hallberg (2000) Small- and medium-scale enterprises (SMEs) are a very heterogeneous group. They include a wide variety of forms - village handicraft makers, small machine shops, restaurants, and computer software firms - that possess a wide range of sophistication and skills, and operate in very different markets and social environments. Their owners may or may not be poor. Some are dynamic, innovative, and growth-oriented; others are traditional "lifestyle" enterprises that are satisfied to remain small. According to Matlay, $\mathrm{H}$ Westhead, P, (2005), "SMEs make significant contributions to the socioeconomic and political environment of most developed and developing nations as well In some countries, SME owners and workers are (or are perceived to be) dominated by members of particular ethnic groups, such as the native pribumi in Indonesia or indigenous groups in Bolivia, the Chinese in Malaysia and the Igbos in Nigeria. According to miller (1983, p.780): in general theorist would not call a firm entrepreneurial if it changed its technology or product line-... simply by directly imitating competitors while refusing to take any risks. Some proactiveness would be essential as well. By the same token, risk-taking firms that are highly leveraged financially are not necessarily entrepreneurial. They must engage in product- market or technological innovation.

In a global context, a general definition of SMEs using size and scale of operation is not easy, but within the fixed coordinates of national boundaries, (Nigeria) it might be relatively easier. At the 13th Council meeting of the National Council on Industry held in July, 2001 Micro, Small and Medium Enterprises (MSMEs) were defined by the Council as follows:

Micro/Cottage Industry An industry with a labour size of not more than 10 workers, or total cost of not more than N1.50 million, including working capital but excluding the cost of land.

Small-scale Industry An industry with a labor size of 11-100 workers or a total cost of not more thanN50 million, including working capital but excluding the cost of land.

Medium Scale Industry: An industry with a labour size of between 101-300 workers or a total cost of over N50 million but not more than N200 million, including working capital but excluding the cost of land. A large scale industry with a labour size of over 300 workers or a total cost of over N200 million, including working capital but excluding the cost of land. All this at a time Nigeria has devalued her currency. Small and Medium Size Enterprises (SME) are the most common employers across the world. In 48 out of 76 nations covered in Ayyagari, Beck and Demirgüç-Kunt (2007), SMEs employed more than 50\% of the formal workforce. In addition, Ayyagari, Demirgüç-Contained Vojislav (2011) finds that small firms and mature firms have the highest levels of total employment and small firms and young firms have the highest rates of job creation.SMEs are a fundamental part of a dynamic and healthy economy.

Nigeria as a developing country with the introduction of the National Policy on MSMEs has addressed the issue of definition as to what constitutes micro, small and medium 
enterprises. The definition adopts a classification based on dual criteria, employment and assets (excluding land and buildings) as shown below (see Table 1)

\begin{tabular}{|c|c|c|}
\hline Category of enterprises & Numbers of Employees & $\begin{array}{c}\text { Capital investment } \\
\text { \#N=assest Excl. Land \& } \\
\text { Building }\end{array}$ \\
\hline Large enterprises & $201+$ & Above 200 million \\
\hline Medium enterprises & $50-199$ & 50 million-200 million \\
\hline Small enterprises & $10-49$ & 1.5 million- 50 million \\
\hline Micro enterprise & $1-10$ & Up to 1.5 million \\
\hline
\end{tabular}

Source: Central Bank of Nigeria (CBN) (2007)

Micro Enterprises are those enterprises whose total assets (excluding land and buildings) are less than Five Million Naira with a workforce not exceeding ten employees. Small Enterprises are those enterprises whose total assets (excluding land and building) are above Five Million Naira but not exceeding Fifty Million Naira with a total workforce of above ten, but not exceeding forty-nine employees. Medium Enterprises are those enterprises with total assets excluding land and building) are above Fifty Million Naira, but not exceeding Five Hundred Million Naira with a total workforce of between 50 and 199 employees. If there exists a conflict on classification between employment and asset criteria (for example, if an enterprise has assets worth seven million Naira (N7M) but employs 7 persons), the employmentbased classification will take precedence and the enterprise would be regarded as micro.

In Nigeria, there has been lots of effort in strengthening the performance Micro, Small and medium scale enterprise has, it is called in Nigeria. Many initiatives and programs, facilitating the creation, resuscitation and stimulation of the growth and development of the Micro, Small and Medium Enterprises sector of the Nigerian economy. Other recent government efforts to stimulate the sector include the following:

(i) The Microfinance Policy, Regulatory, and Supervisory Framework for Nigeria.

(ii) The Small and Medium Enterprises Equity Investment Scheme (SMEEIS)

(iii)The N200 billion Small and Medium Scale Enterprises Guarantee Scheme (SMECGS)

(iv) The N200 billion SME Restructuring/Refinancing Fund

(v) The N100 billion Cotton, Textile and Garment (CTG) Fund

(vi) The N2 billion NERFUND Facility

(vii) The N5 billion Dangote Fund for MSMEs

(viii) The Counterpart Funding Scheme of the Bank of Industry

(ix) The Youth Enterprise with Innovation in Nigeria (You Win) Programme

(x) Train to Work (TRATOW) Initiative

(xi) Campaign for Patronage of Made-in-Nigeria Products

The Micro, Small and Medium Enterprises Sub-sector has been identified as one of the critical elements to the achievement of the countryes vision 20-2020. MEMEs preliminary report (2010) The sub-sector has been globally acknowledged as the engine that drives the socioeconomic transformation of both the developing and developed countries. A nurtured and the well structured (MSMEs) sector contributes significantly to employment generation, wealth creation, poverty reduction and sustainable economic growth and development. In par- 
allel to this, the role of entrepreneurs has been undeniable and can never be circumvented. It must be known that entrepreneurs have to be entrepreneurial oriented and improve the level of entrepreneurial in order to strengthen the resilience of the economy in a competitive and challenging environment. The best of all the best criterion for entrepreneurs who want to be successful which has been argued by researchers is requiring them to have an Entrepreneurial Orientation (EO) Lumpin \& Dess (2001) Covin and Adler (1989) suggest that the strength of the relationship between entrepreneurs' orientation and firm performance is contingent upon the set of business practices and competitive tactics chosen by the firm.

Entrepreneurial Orientation is defined as the willingness of firms to display proactive and innovative actions and to take calculated risks in an effort to create and exploit environment, opportunities (Kreiser 2002; Covin \& Slevin, 1989; Miller, 1983; Miller \& Friesen, 1982). The several of the dimensions of EO such as innovation, pro-activeness and risk taking qualities will be imitated and significant to the growth and business performance of SMEs in the area (Fairoz, 2010). In addition, EO (Madsen, 2007b) may be used as a medium by management to discover and exploit opportunities and implicitly affects firm performance.

Schollhammer (1982) sited "Entrpreneurship is the key element for gaining competitive advantage and consequently greater financial rewards. "Accordingly, any system or "macro" models of entrepreneurship, and certainly any model of entreprenership as firm behavior, would be remiss to ignore or subordinate the firm performance .

Many reasons have been adduced for the non-encouraging situation of the SMEs in Nigeria and many scholars have documented financial resources, poor infrastructure, managerial inefficiency, and unnecessary interventions by the government as factors affecting SME performance (Osotimehin, Jegede, and Olajide 2012; Udjo 2011; Akande and Ojokuku 2008; Alarape 2007b), yet only a few studies linked the firm's entrepreneurial orientation (EO) to SME performance in Nigeria.According to Alarape (2013) The majority of the 'EOperformance' studies were done on SMEs in America, Europe, and Asia. A far less number of studies were from South, East, and North Africa. Within the available studies, there are controversies about the nature of the relationship between EO and firm performance. For examples, Ferreira and Azevedo (2007) expressed the relationship between EO and firm performance as positive, Hart (1992) described it as negative, while Rauch et al. (2004) did not find any significant relationship between EO and firm performance. Lumpkin and Dess (2001) found a positive relationship, but concluded that the relationship is not a simple one but contingent upon environmental conditions. However, Brown and Kirchhoff (1997) failed to identify any direct impact of the environmental variables upon the relationship between EO and firm performance.

This study is intended to contribute to the precarious dearth of small and medium enterprise in Nigeria and highlight the importance EO as the remedy for the productivity of the SMEs and performance of SMEs in Nigeria and West Africa, to also shed light on the intricacies of the effects of EO on firm performance by X-raying the contributions of the SMEs in Nigeria. Hence, it will enriches the knowledge of the contributions of EO influence the productivity. Additionally, it will also consider the attitudes of entrepreneur and its influence on the EO which will lead to productivity, so that it will stop the mis-specification of the relationship of how EO is being driven and executed across the functional activities of SMEs.

\section{LOCUS OF SME IN NIGERIA ECONOMY}

SMEs are major contributors to private sector employment in Nigeria Empirical studies have shown that SMEs contribute to over $55 \%$ of GDP and over $65 \%$ of total employment in 
high income countries.SMEs and informal enterprises, account for over $60 \%$ of GDP and over $70 \%$ of total employment in low income countries, while they contribute about $70 \%$ of GDP and $95 \%$ of total employment in middle income countries. SMEs also play significant contribution in the transition of agriculture-led economies to industrial ones furnishing plain opportunities for processing activities which can generate a sustainable source of revenue and enhance the development process.

Small and Medium-sized Enterprises (SMEs) in Nigeria, as defined by Small and Medium Industries Equity Investment Scheme (SMIEIS), are enterprises with a total capital employed not less than N1.5 million, but not exceeding N200 million, including working capital, but excluding the cost of land and/or with a staff strength of not less than 10 and not more than 300. In this work, this definition was adopted, however an observation of some of the surveyed SMEs are with a total capital less than N1.5 million and a lower staff strength. They are estimated to generate about 50\% of the Gross Domestic Product (Odeyemi, 2003) and employ about $70 \%$ of the industrial work force in the country (Adebusuyi, 1997). The SMEs is made up of a mixed blend of businesses ranging from distributive trade, which constitute about $50 \%$ of the SMEs, $10 \%$ in manufacturing, $30 \%$ in agriculture and $10 \%$ in services all operating in different parts of the country. (See table 2)

Table 2. Characteristic of SMEs in Nigeria.

\begin{tabular}{|c|c|c|c|}
\hline $\begin{array}{c}\text { MSEMs } \\
\text { charatertics }\end{array}$ & Micro enterpries & Small business & Medium enterprises \\
\hline Skills & $\begin{array}{l}\text { Low: uneducated but } \\
\text { dynamic. Sole ownership }\end{array}$ & $\begin{array}{l}\text { Medium: have technology } \\
\text { competence, engage in train- } \\
\text { ing and invest in apprentice- } \\
\text { ship system. Basic education } \\
\text { at the very least high school } \\
\text { leaving certificate or trade } \\
\text { technical certificate }\end{array}$ & $\begin{array}{l}\text { High: undertake technolo- } \\
\text { gy upgrading, design ad- } \\
\text { aptations in response to } \\
\text { market. Highly educated, } \\
\text { often with a university } \\
\text { degree or higher }\end{array}$ \\
\hline Technology & None to low & Low to medium & Medium to high \\
\hline Competition & Medium to high & High & Medium to high \\
\hline Products & $\begin{array}{l}\text { Retail, arts and crafts, } \\
\text { textiles, services, e.g. } \\
\text { Salons, tailoring }\end{array}$ & $\begin{array}{c}\text { Manufacturing, chemicals } \\
\text { and Pharmaceuticals, orga- } \\
\text { nized retail }\end{array}$ & $\begin{array}{l}\text { Telecom, IT, specialized } \\
\text { Retail service e.g. restau- } \\
\text { rants, entertainment }\end{array}$ \\
\hline Markets & Local & Local, national, regional & Local, national, regional \\
\hline $\begin{array}{l}\text { Links with BDS } \\
\text { providers and other } \\
\text { support institutions }\end{array}$ & $\begin{array}{l}\text { Very limited: few links } \\
\text { with donor sponsored } \\
\text { Providers }\end{array}$ & $\begin{array}{l}\text { Limited: some links with } \\
\text { donor and private sector } \\
\text { providers complemented by } \\
\text { in-house technical Training, } \\
\text { accounting and some routine } \\
\text { functions, e.g. legal, man- } \\
\text { agement and technical con- } \\
\text { sultancy }\end{array}$ & Extensive \\
\hline
\end{tabular}

SOURCE: Adapted from World Bank 2002.

Nigeria SMEs adopted a common definition of SMEs to fulfill the criteria in the various sectors and subsectors, SMEs in Nigeria is based on three factors namely; Acitivity, turnover, and size.

An enterprise is considered to be an SME based on the annual turnover or number of full time employees, Roslida (2011) a report by SME survey report 2010/2011, the survey showed that there were 22,918 total establishments in Nigeria see (table 3) covering the whole 
sectors which is very small if compare to some Asian country i.e. Malaysia has 552,849 of just of three main sectors namely; manufacturing, services and agriculture (Rosalida 2011).Table 3. Total Number of Small and Medium Enterprises by Sector.

\begin{tabular}{|c|c|c|c|c|c|}
\hline SECTOR & $10-49$ & $50-199$ & & & TOTAL \\
\hline & $\begin{array}{l}\text { Num- } \\
\text { ber }\end{array}$ & Percentage & Number & Percentage & \\
\hline $\begin{array}{l}\text { Agriculture, Hunting, } \\
\text { Forestry and Fishing }\end{array}$ & 696 & 92.77 & 54 & 7.23 & 750 \\
\hline Mining and Quarrying & 134 & 80.43 & 33 & 19.57 & 167 \\
\hline Manufacturing & 5,939 & 89.28 & 713 & 10.72 & 6,652 \\
\hline $\begin{array}{l}\text { Building and Construc- } \\
\text { tion }\end{array}$ & 194 & 81.13 & 45 & 18.87 & 239 \\
\hline $\begin{array}{c}\text { Wholesale and Retail } \\
\text { Trade; Repair of Motor } \\
\text { Vehicles and House- } \\
\text { hold goods }\end{array}$ & 3,916 & 96.90 & 125 & 3.10 & 4,041 \\
\hline Hotels and Restaurants & 2,088 & 94.52 & 121 & 5.48 & 2,209 \\
\hline $\begin{array}{l}\text { Transport, Storage and } \\
\text { Communication }\end{array}$ & 680 & 83.89 & 131 & 16.11 & 811 \\
\hline $\begin{array}{c}\text { Financial Intermedia- } \\
\text { tion }\end{array}$ & 2,166 & 93.22 & 158 & 6.78 & 2,323 \\
\hline $\begin{array}{l}\text { Real Estate, Renting } \\
\text { and Business Activities }\end{array}$ & 908 & 94.62 & 52 & 5.38 & 960 \\
\hline Education & 1,508 & 93.75 & 101 & 6.25 & 1,608 \\
\hline Health and Social Work & 2,542 & 95.75 & 113 & 4.45 & 2,654 \\
\hline $\begin{array}{l}\text { Other Community, So- } \\
\text { cial and Personal Ser- } \\
\text { vice Activities }\end{array}$ & 495 & 97.98 & 10 & 2.02 & 505 \\
\hline TOTAL & 21,264 & 92.78 & 1,654 & 7.22 & 22,918 \\
\hline
\end{tabular}

Source:Smedan 2011 


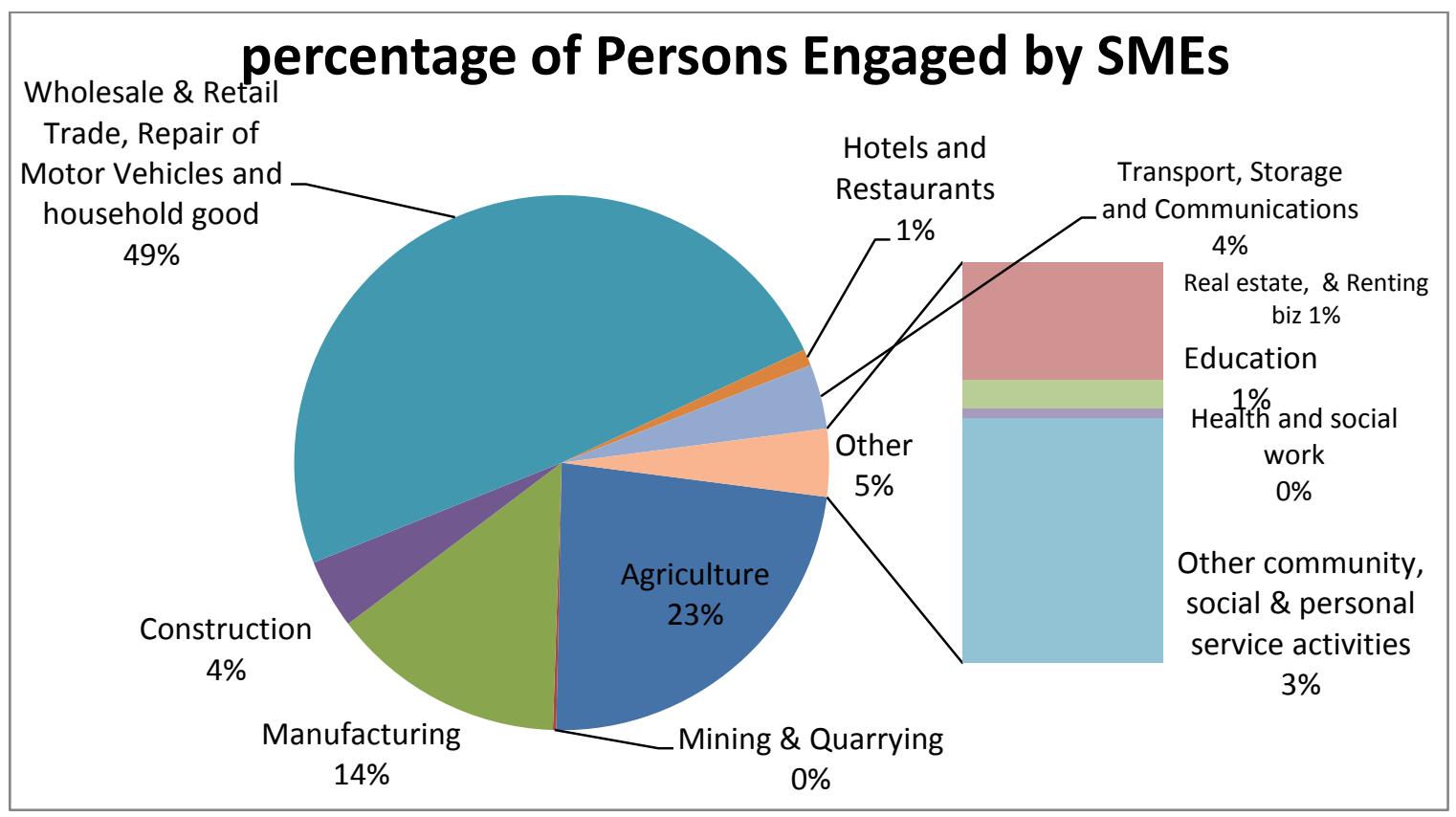

Source: National Bureau of statistics (2012)

SMEs in Nigeria is categoried into sectors (smedan 2012) all the sectors are accounting for the 22,918 percentage the agriculture account for $23 \%$ of the person engage by SMEs, the wholesale and retail trade, repair of motor vehicles and house hold goods account for the largest percentage which is $49 \%$ this happen because most of the road are not really motorable this sector enage in repair of body part to the damage vehicles and sells of house hold goods the hotel and restaurants is $1 \%$, construction account for $4 \%$ the manufacturing sector is carrying $14 \%$ and while the mining and quarrying is a good as been in moribund. The diagram of the percentage of person(s) engage by Nigeria SMEs is indicated in (chart 1) above. In regards to location, Lagos has the highest number of establishment of 4,535 small scale followed by Kano, Oyo and Kaduna with 1,740,1,300 and 1,137 respectively. The most detailed of number of establishments by state is indicated in (Table 4) below.

Table 4. Number of Small and Medium Enterprises by State.

\begin{tabular}{|c|c|c|c|c|c|c|}
\hline & & \multicolumn{2}{|c|}{$10-49$} & \multicolumn{2}{c|}{$50-199$} & \\
\hline S/N & State & Number & percentage & Number & Percentage & Total \\
\hline 1 & Abia & 526 & 98.62 & 7 & 1.38 & 534 \\
\hline 2 & Adamawa & 235 & 95.58 & 11 & 4.42 & 245 \\
\hline 3 & Akwa Ibom & 275 & 87.48 & 39 & 12.52 & 315 \\
\hline 4 & Anambra & 656 & 89.01 & 81 & 10.99 & 737 \\
\hline 5 & Bauchi & 497 & 91.02 & 49 & 8.98 & 545 \\
\hline 6 & Bayelsa & 134 & 100.00 & 0 & 0.00 & 134 \\
\hline 7 & Benue & 357 & 95.63 & 16 & 4.37 & 374 \\
\hline 8 & Borno & 131 & 77.95 & 37 & 22.05 & 168 \\
\hline 9 & Cross River & 318 & 87.02 & 47 & 12.98 & 365 \\
\hline 10 & Delta & 576 & 94.64 & 33 & 5.36 & 608 \\
\hline
\end{tabular}




\begin{tabular}{|c|c|c|c|c|c|c|}
\hline 11 & Ebonyi & 232 & 94.99 & 12 & 5.01 & 244 \\
\hline 12 & Edo & 899 & 96.83 & 29 & 3.17 & 929 \\
\hline 13 & Ekiti & 280 & 98.41 & 51 & 1.59 & 285 \\
\hline 14 & Enugu & 402 & 93.03 & 30 & 6.97 & 432 \\
\hline 15 & Gombe & 225 & 88.02 & 31 & 11.98 & 255 \\
\hline 16 & Imo & 534 & 92.97 & 40 & 7.03 & 574 \\
\hline 17 & Jigawa & 217 & 93.81 & 14 & 6.19 & 231 \\
\hline 18 & Kaduna & 1,137 & 88.72 & 145 & 11.28 & 1,282 \\
\hline 19 & Kano & 1,740 & 96.21 & 69 & 3.79 & 1,808 \\
\hline 20 & Katsina & 464 & 86.86 & 70 & 13.14 & 535 \\
\hline 21 & Kebbi & 221 & 95.13 & 11 & 4.87 & 232 \\
\hline 22 & Kogi & 328 & 96.67 & 11 & 3.33 & 340 \\
\hline 23 & Kwara & 415 & 93.66 & 28 & 6.34 & 443 \\
\hline 24 & Lagos & 4,146 & 91.43 & 389 & 8.57 & 4,535 \\
\hline 25 & Nassarawa & 387 & 92.43 & 32 & 7.57 & 418 \\
\hline 26 & Niger & 433 & 90.48 & 46 & 9.52 & 478 \\
\hline 27 & Ogun & 506 & 92.73 & 40 & 7.27 & 546 \\
\hline 28 & Ondo & 596 & 97.13 & 18 & 2.87 & 614 \\
\hline 29 & Osun & 100 & 100.0 & 0 & 0.00 & 100 \\
\hline 30 & Oyo & 1,300 & 93.26 & 94 & 6.74 & 1,394 \\
\hline 31 & Plateau & 613 & 92.56 & 49 & 7.44 & 663 \\
\hline 32 & Rivers & 662 & 91.65 & 60 & 8.35 & 723 \\
\hline 33 & Sokoto & 562 & 96.68 & 19 & 3.32 & 581 \\
\hline 34 & Taraba & 242 & 97.80 & 5 & 2.20 & 247 \\
\hline 35 & Yobe & 150 & 96.50 & 5 & 3.50 & 156 \\
\hline 36 & Zamfara & 341 & 100.00 & 0 & 0.00 & 341 \\
\hline \multirow[t]{2}{*}{37} & $\begin{array}{c}\text { Federal } \\
\text { capital }\end{array}$ & 427 & 84.17 & 80 & 15.83 & 507 \\
\hline & TOTAL & 21,264 & 92.78 & 1,654 & 7.22 & 22,918 \\
\hline
\end{tabular}

Source : Survey MSME (2012)

In regards to location, According to survey of report of SMEs in Nigeria (2012) Lagos has the highest number of establishment of $8.57 \%$ (4,535), followed by Kano and Oyo respectively.

This scenario of which a huge amount of SMEs establishment has a location in Lagos state is because of the population (http://www.lagosstate.gov.ng/pagelinks.php? $p=6$ ) as of 2006, the population of Lagos state was 17.5, the former capital of Nigeria located in the southwestern of the country which double as the industrialized location equipped with port services. In term of Contribution of SME to Each GDP Economic Activity (Percentage).

Table 5. Percentage of each sector to Nigeria GDP.

\begin{tabular}{|c|c|c|c|c|}
\hline SECTOR & Micro & Small & Medium & Total \\
\hline Agriculture, Hunting, Forestry and Fishing & 69.58 & 25.27 & 3.16 & 98.01 \\
\hline Mining and Quarrying & 4.25 & 35.44 & 28.09 & 67.78 \\
\hline Manufacturing & 7.31 & 29.25 & 27.25 & 63.74 \\
\hline Building and Construction & 0.49 & 1.96 & 8.31 & 10.76 \\
\hline Wholesale and Retail Trade: Repair of Motor & 3.94 & 46.71 & 17.33 & 67.98 \\
\hline
\end{tabular}




\begin{tabular}{|c|c|c|c|c|}
\hline Vehicles and Household goods & & & & \\
\hline Hotels and Restaurants & 4.21 & 28.10 & 8.31 & 40.62 \\
\hline Transport, Storage and Communications & 6.44 & 10.54 & 22.76 & 39.74 \\
\hline Financial Intermediation & 0.97 & 3.10 & 1.24 & 5.32 \\
\hline Real Estate, Renting and Business Activities & 80.40 & 17.44 & 1.29 & 99.13 \\
\hline Education & 8.00 & 15.00 & 25.00 & 48.00 \\
\hline Health and Social Work & 23.66 & 24.53 & 25.63 & 73.82 \\
\hline $\begin{array}{c}\text { Other Community, Social and Personal Service } \\
\text { Activities }\end{array}$ & 99.94 & 0.02 & 0.02 & 99.98 \\
\hline
\end{tabular}

Source: Nigeria National Bureau of Statistics (2013)

\section{Agriculture, Hunting, Forestry and Fishing}

Agriculture in Nigeria can be broken into two major segments; private farmers and corporate farms. The private farmers constitute the highest percentage both in number and output, and by definition they are classified as micro and small enterprises while the corporate farms are largely medium enterprises while a small percentage operates at large scale. From the above table it shows that MSMEs contribute 98.01 percent of the GDP produced in this sector. Further breakdown of this result showed that the micro enterprises in this sector contributed 69.58 percent to nominal GDP, while the small and medium enterprises contributed 25.27 and 3.16 percent of the GDP produced from this sector.

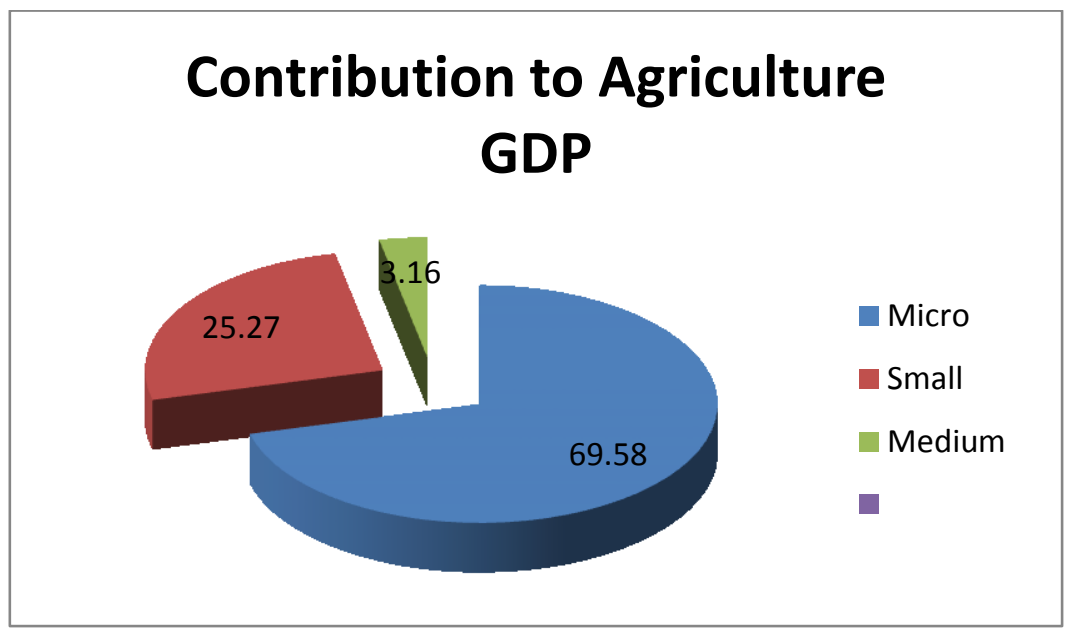

\section{Mining and Quarrying}

Activities in this sector comprise of coal mining, metal ore and other mining \& quarrying activities such as stone crushing. At N30.97 billion worth of MSMEs output in this sector, it was found that MSMEs contribute 67.78 per cent to activities in this sector. A breakdown of this contribution showed that most of the activities were from small and medium scale enterprises in this sector, which contributed 35.44 and 28.09 per cent, respectively, while the micro enterprises contribute 4.25 per cent. 


\section{Contribution to Mining \& Quarrying GDP}

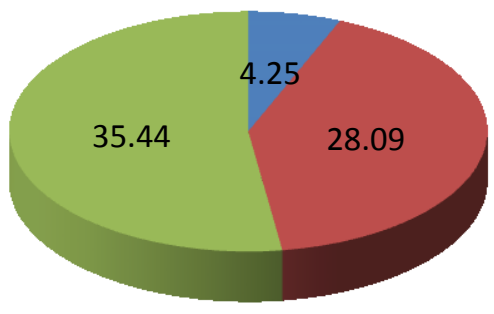

Mirco

Medium

- small

\section{Manufacturing}

The manufacturing sector as compiled in 33 activities sectors of Nigeriaes GDP is made up of oil refining, cement and other manufacturing. However, given the large scale nature of the oil refining and cement sub-sectors, this study found that SME activities were prominent in the other manufacturing sub-sector. Activities under the other manufacturing sub-sector includes food, beverages \& tobacco, textile, apparel \& footwear, wood \& wood products; pulp, paper \& publishing, non-metallic products, domestic/industrial plastic \& rubber, electrical \& electronics, basic metal, iron \& steel and motor vehicle \& miscellaneous assembly. The analysis showed that the SMEs contributes 63.74 per cent to the other manufacturing sector GDP with micro enterprises contributing 7.31 per cent, small enterprises contributing 29.25 per cent and the medium scale enterprises contributing 27.18 per cent.

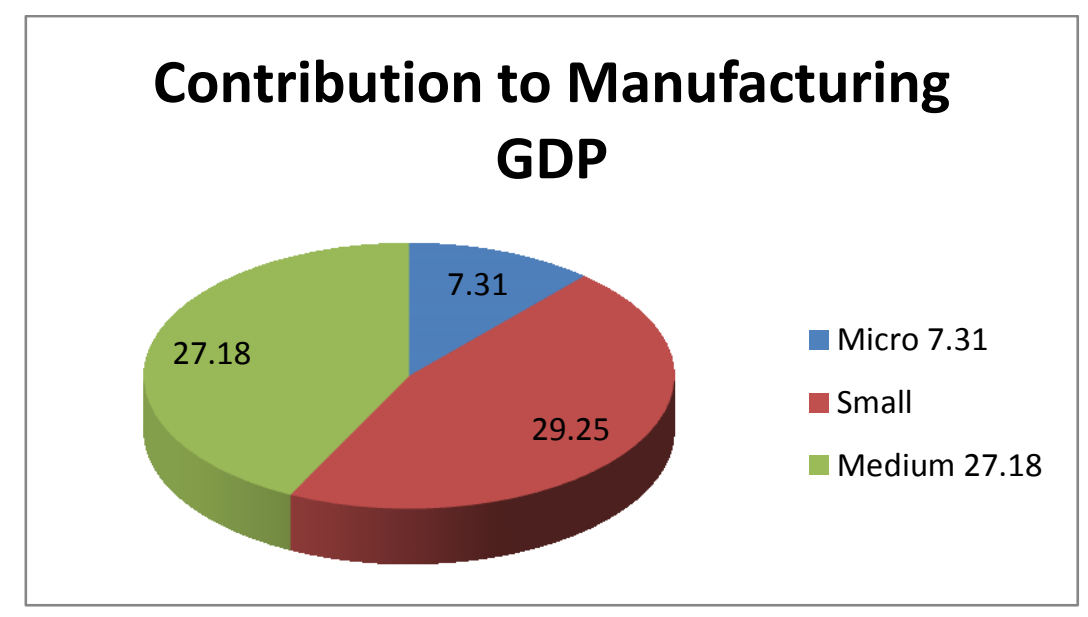

\section{Building and Construction}

Activities in this sector can be classified into two distinct groups; building such as residential and non-residential and other construction which includes roads, bridges, dams, airport, etc. In every aspect of this sector in Nigeria SMEs can be found either at the local government, state or national level. Activities in this sector are more on the building of residential and non-residential houses by both the private and public sector. Most of the activities in this 
regard are carried out at SMEs level. However, a large chunk of activities in this sector is carried out in construction activities which are usually high-valued government financed projects executed by the various tiers of government in the country. Analysis of the data collected from the sector in 2010 showed that the SMEs activities contribute 10.76 per cent of the total value of activities in this sector, out of this portion the medium enterprises contributed 8.31 per cent which the small and micro enterprises contributed 1.96 and 0.49 per cent respectively.

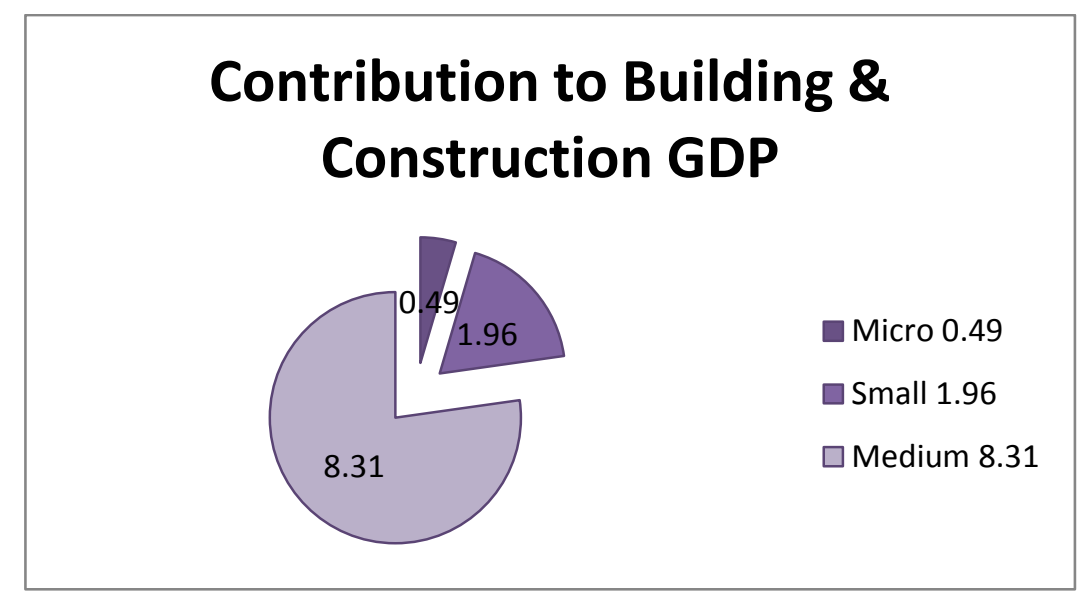

\section{Wholesale and Retail Trade}

The wholesale and retail trade activities constitute a dominant sector in business activities engaged by a majority of Nigerians. Due to the large population of the country and the geographical spread, activities in this sector form a major component of the people ${ }^{e e}$ means of economic sustenance. Operators in this sector depending on their capital can engage in trading activities in various scales either micro, small, medium to large. However, given the definition of SMEs adopted in this study it was found that despite the large capital outlay used by most operators in this sector their employment size still qualify them to be classified as small scale enterprises. The study found that SMEs in this sector contribute as much as 67.98 per cent of total output from this sector; this was largely driven by the small scale enterprises which contribute 46.71 per cent while the medium scale and micro enterprises contribute 17.33 and 3.94 per cent, respectively.

\section{Wholesale \& Retail Trade GDP}

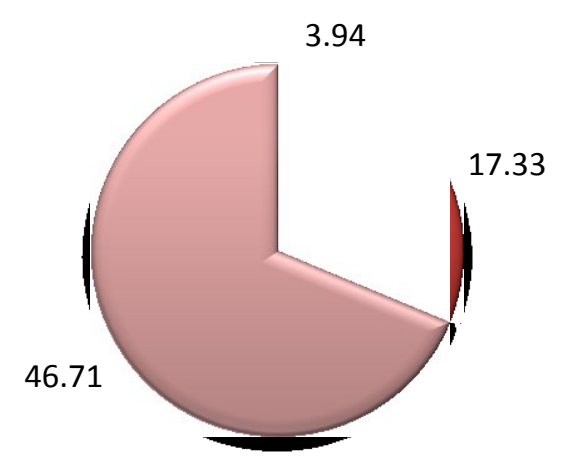

Dicro

$\square$ Medium

$\square$ Small 


\section{Hotels and Restaurants}

The study found that the hotel component of the sector comprises of small, medium and large scale enterprises while the restaurants component is dominated by micro enterprises. The analysis showed that SMEs contribute 40.62 per cent to activities in this sector ${ }^{\text {re }}$ GDP. It further showed that 28.10 per cent of this ratio comes from small scale enterprises, 8.31 per cent from medium scale enterprises and 4.21 per cent from micro enterprises

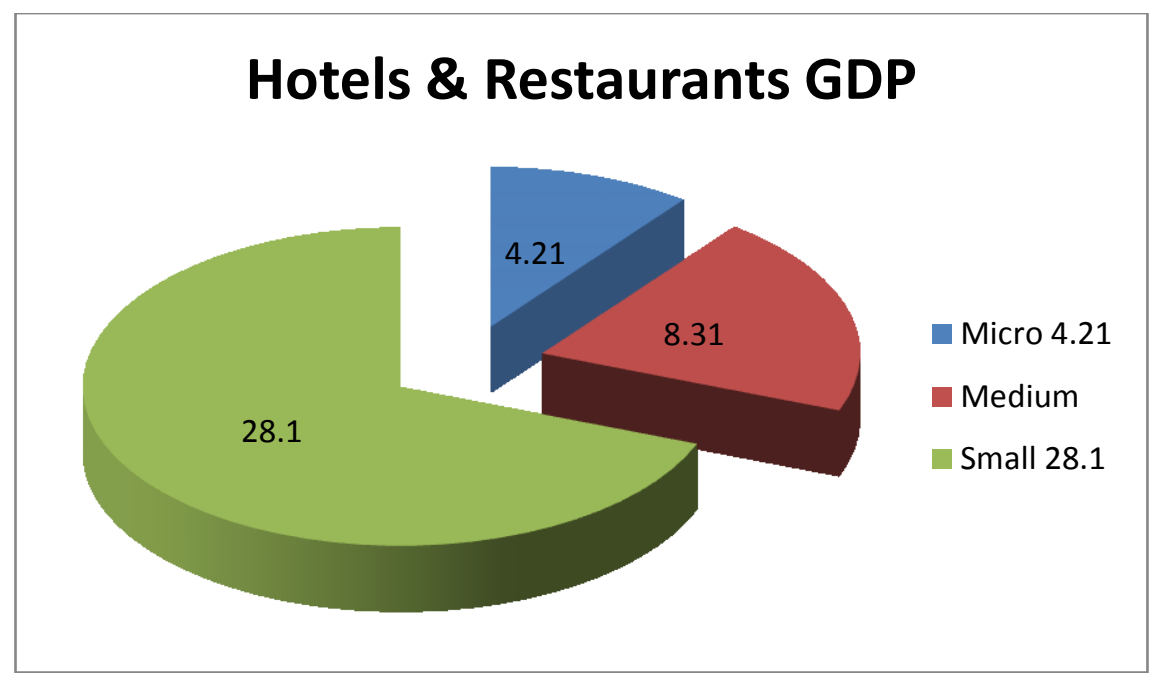

\section{Transport, Storage and Communications}

Activities captured under this grouping include telecommunications, postal/courier services, storage facilities and transportation, which comprises road, rail, water, air and other transport services. The telecommunications, air transport, postal services, rail transport and water transportation were found to be dominated by large scale enterprises. The study found that SMEs operators in this sector contributes 39.74 per cent to the sectores output. Of this percentage, the medium scale enterprises contribute 22.76 per cent, followed by the small scale enterprises which contribute 10.54 per cent and micro enterprises which contribute 6.44 per cent.

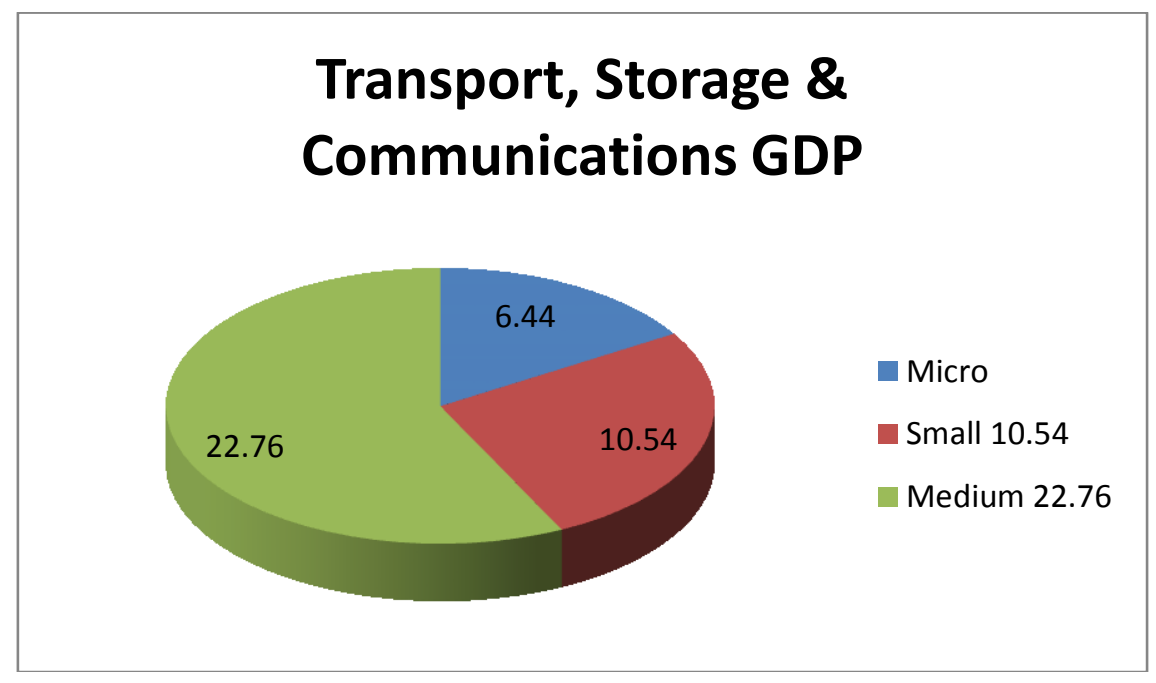




\section{Financial Intermediation}

Activities in this sector were captured from the formal and informal financial intermediaries. On the formal part are the banks and other financial institutions, including insurance companies while the informal intermediaries operate in form cooperative groups. The study showed that the contribution of SMEs to this sectores GDP stood at 5.32 per cent in 2010 which reflected that the small scale intermediaries contributed the highest with 3.10 per cent while the medium and micro enterprises contributed 1.24 and 0.97 per cent, respectively.

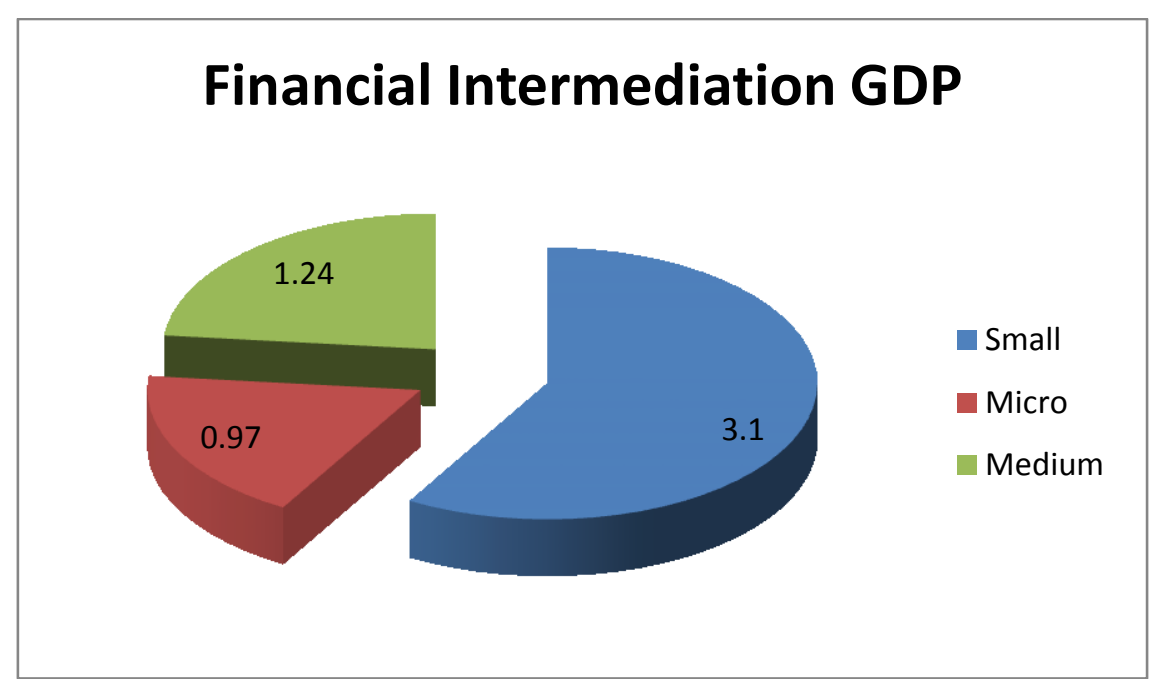

\section{Real Estate, Renting and Business Activities}

The structure of activities in this sector in Nigeria is usually carried out on micro scale level due to the capital and human resource requirements. Analysis of the GDP from this sector showed that SMEs contribute 99.13 per cent of the total output from this sector. This dominated by the output from micro enterprises which contributes 80.40 per cent. The data showed that small and medium enterprises contributed 17.44 and 1.29 per cent, respectively, to this sectores GDP in 2010.

\section{Renting \& Business Services GDP}

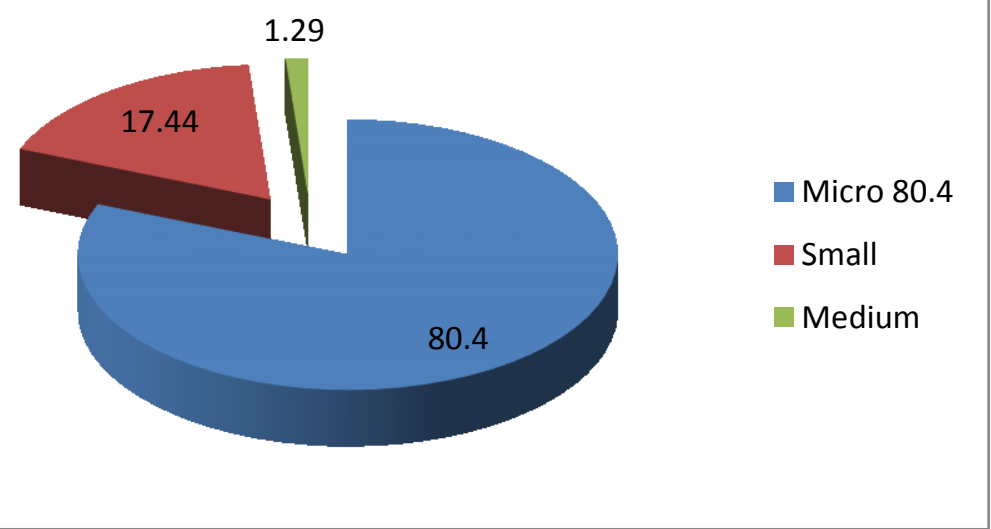




\section{Education}

The (SMEs) operators in this sector were found to contribute 48.00 per cent of the education sector GDP. A breakdown of this ratio shows that medium scale enterprises contributed 25.00 per cent, the small scale enterprises contributed 15.00 per cent and the micro operators contributed 8.00 per cent.

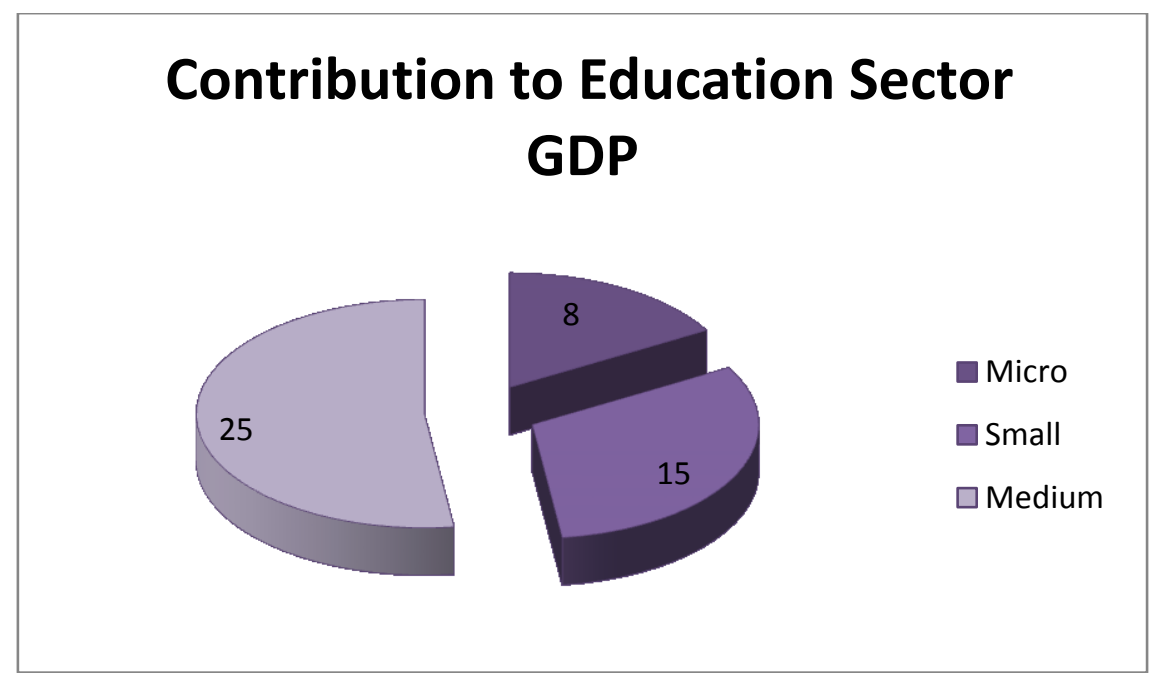

\section{Health and Social Work}

The contribution of SMEs to the total GDP from this sector in 2010 stood at 73.82 per cent, which reflected that micro enterprises contributed 23.66 per cent, small enterprises 24.53 percent and medium scale enterprises 25.63 percent.

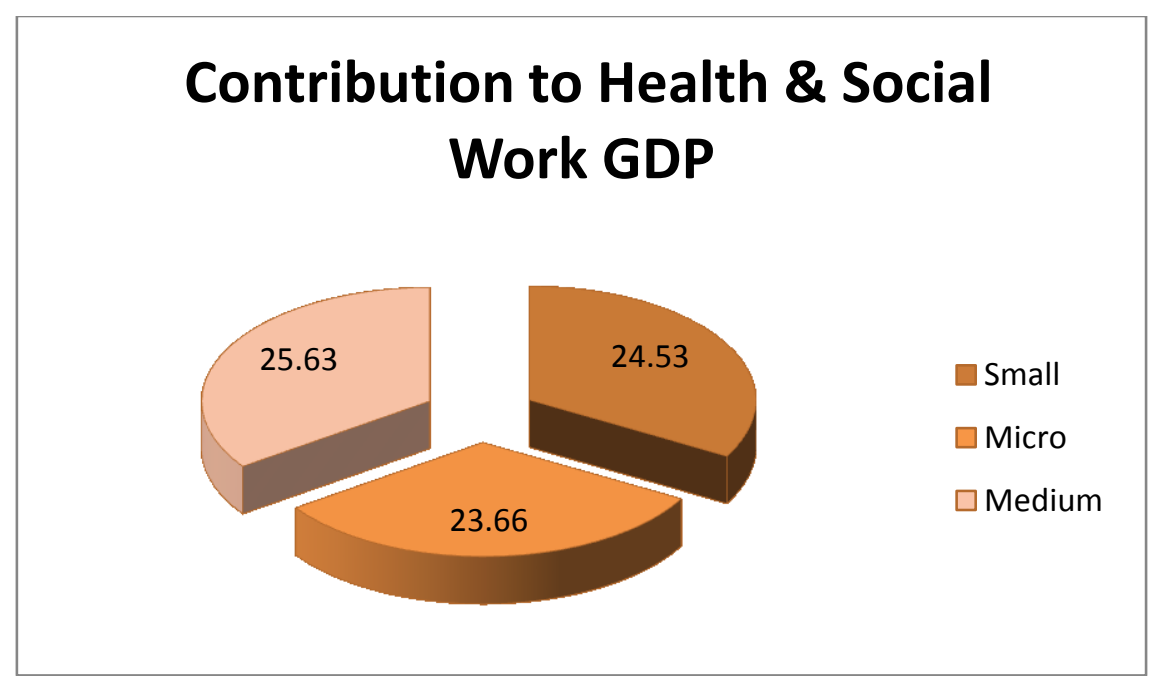

\section{Other Community, Social and Personal Services}

Activities covered under sector include most informal service oriented activities such as barbing saloon, hairdressing, laundry services, etc. This sector is mostly controlled by micro 
scale enterprises which contributed 99.94 per cent to the sector"s GDP, while the small and medium scale enterprises contributed 0.02 per cent each resulting in a total contribution of 99.98 per cent by SMEs

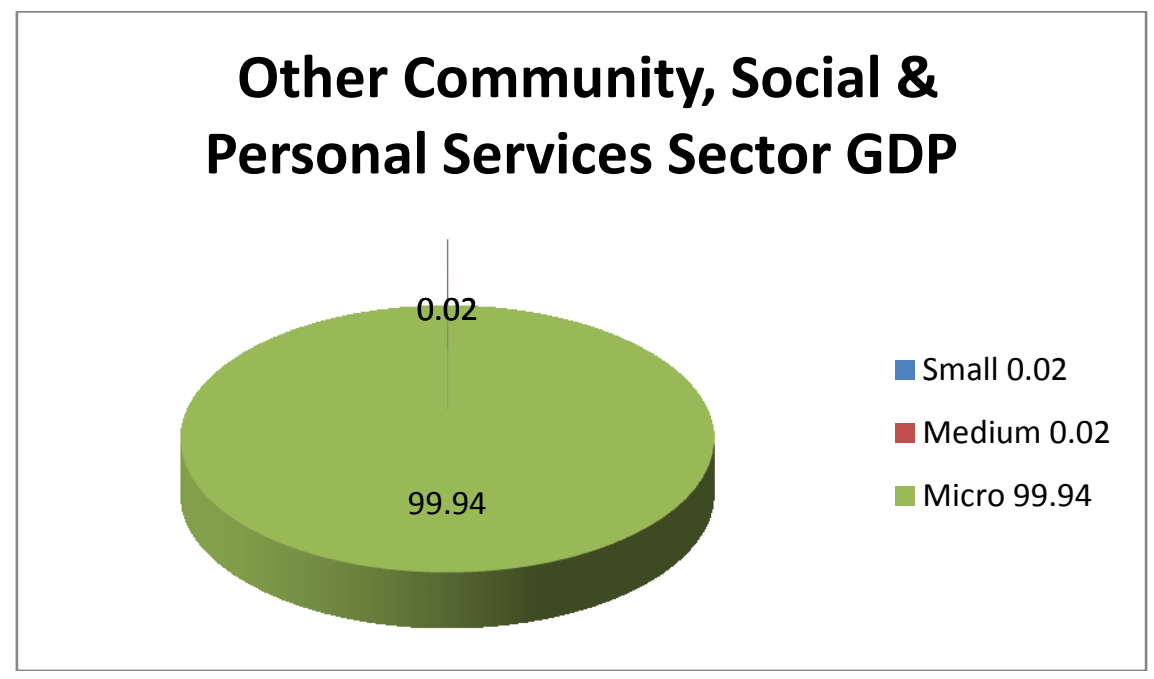

The survey result showed that Lagos State has the highest number of small and medium enterprises, comprising 4,146 small enterprises and 389 medium enterprises, totalling 4,535 enterprises. The lowest number of enterprises is recorded in Bayelsa State with 134 small enterprises and zero medium enterprise. In terms of micro enterprises, Lagos state had the highest figure of 880,805 enterprises, followed by Kano (872,552 enterprises), while Abuja (FCT) had the lowest record of (272,579 enterprises(SMEs report by Smedan 2012/2013). As of today there are two interesting changes in SMEs growth in Nigeria The oil sector experienced production challenges. The average daily production of crude oil in the Third Quarter of 2014 was recorded at 2.15 million barrels per day (mbpd), a decrease from $2.26 \mathrm{mbpd}$ recorded in the Third Quarter of 2013 and2.21 mbpd recorded in Second Quarter of the year 2014 was a decline in oil GDP by 3.6 percent in the Third Quarter of 2013, This was also lower relative to 5.47 percent in the Second Quarter of 2014.

The Oil sector contributed approximately 10.45 percent to real GDP in the third quarter of 2014, lower from the 10.76 percent contribution in the Second Quarter of 2014, and the 11.51 percent contribution recorded during the Third Quarter of 2013 (National Bureau of Statistics 2014) The non-oil sector growth was driven by growth in activities recorded in the Crop Production, Textile, Apparel and Footwear; Telecommunications, and Real Estate sectors. In the third quarter of 2014, the non-oil sector recorded 7.51 percent growth in real terms, lower compared to 8.46 percent at the corresponding period in 2013, yet higher than 6.71 percent in the second quarter of 2014 In nominal terms, the sector recorded a negative growth of 14.68 percent (year-on-year) in the Third Quarter of 2014, 3.58 percentage points lower than the growth in the corresponding quarter of 2013 and 27.90 percentage points higher from growth recorded in the Second Quarter of 2014. Coal Mining and Metal ores were the fastest growing during the period growing by 27.87 percent and 25.30 percent respectively. Quarter on Quarter, the Sector slowed by 11.45 percent, with Quarrying and Other minerals and Crude Petroleum and Natural leading the growth by $12.31 \%$ and $-11.58 \%$ respectively. The contribution of Mining and Quarrying to the Nominal GDP in the third quarter of 2014 was recorded at $10.26 \%$. In real terms, the sector grew by -3.43 percent (year-on-year) in the Third Quarter of 2014, 11.04percentage points higher from rates recorded in the Third Quarter 
of 2013, yet 8.75 percentage points lower from growth recorded in the Second Quarter of 2014. During the Third Quarter, the negative growth was recorded as a result of the decline in crude oil production and the international oil prices. The Crude Oil and Natural Gas sector were the major driver of growth in the sector, growing by -3.60 percent.Quarter-on-quarter, the sector grew by 5.44 percent. Again, Crude Petroleum and Natural gas were the Major driver of growth during the quarter growing by 5.47 percent. The contribution of Mining and Quarrying to the Real GDP in the Third quarter of 2014 was $10.58 \%$, compared to 11.64 percent recorded in the Third Quarter of 2013 and 10.90 percent recorded in the Second Quarter of 2014. ( National Bureau of Statistics 2014).

\section{ENTREPRENEURIAL ORIENTATION AND THE PRODUCTIVITY OF SME IN NIGERIA}

In realization of the vital contributions of SMEs to the attainment of the nation's economic development objectives,

The government (at the federal and state levels) in Nigeria continues to make a number of schemes to support this Subsector In realization of the vital contributions of SMEs to the attainment of the nation's economic development objectives, the government (at the federal and state levels) in Nigeria continues to make a number of schemes to support this Subsector problem in Nigeria. Thus, their contributions to the industrialization process are still generally low when compared with other countries of South East Asia. The development of the SME sub-sector has been constrained by a number of factors, both internal and external, despite the efforts of successive governments to promote the sub-sector. These factors include:

i. Inconsistence policy measure

ii. Unstable macro-economic environment

iii Poor infrastructural facilities, i.e. roads/railway system, water supply, electricity, telecommunications, etc. This is in line with Giwa (2001) on the problems of the Nigerian industrial sector. Inefficiency and effectiveness of the institutional support systems for SMEs. In addition to the above, internal factors that handicap the SMEs in the industrialization process in Nigeria include: i. Low levels of skills: technical and managerial. To buttress the above, Lewis (1977) opined that what Nigerian entrepreneurs lack most is managerial competence. ii. Inability to effectively compete in the local, domestic and the international export markets because the home market is saturated with cheap imported products, poor quality of products or the unfamiliarity with the vagaries of export procedures. In line with the foregoing, Giwa (2001) opined that the influx of fake and substandard products, under invoicing, dumping and malpractices at our ports, placing imported goods at an undue advantage over local manufacturers, are some of the most damaging issues affecting the manufacturing industry. iii. Low levels of process technologies iv. Lack of productive resources. With respect to resources, Ogun and Anyanwu (1999) consider inadequate funding (finance) to be paramount.

According to Amao (1997), the most intractable of these problems is poor access to capital. So wide is the credibility gap that most banks prefer to pay the stipulated government penalty rather than carry out a government directive that a percentage of their funds be set aside to finance SMEs. It is pertinent to reiterate that Nigerian SMEs are usually by sole ownerships (very little or limited liability companies) with limited (though intensive) labor force, centralized administration and management, less access to finance (long term and medium term) and high failure rate. This was supported by the recent report by the Nigeria national bureau of statistics and SMEDAN (2012) pointed out of all the factors militaling against 
SMEs in Nigeria lack of finance also came first (2) Lack of work space since after the finance where will you get space will be the next problem to fight against (3) Weak infrastructure see the list in Table6 through Small and Medium Enterprises Development Agency of Nigeria (SMEDAN) plays an important role in SME development and functions in order to reorganize the challenges.

Table 6. The basic problems of Nigeria SMEs in relations to needs problems.

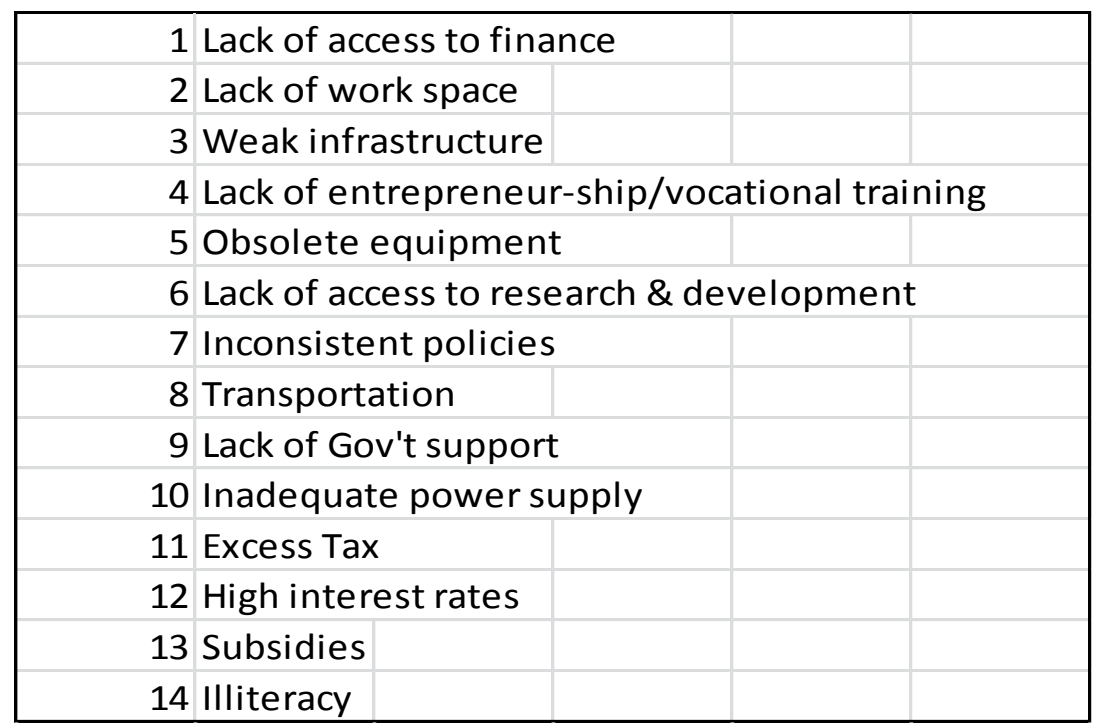

Source : Nigeria national bureau of statistics (2014)

Ogunsiji \& Ladanu (2010) opines that "an entrepreneur is a significant phenomenon at ensuring improved productivity and hence increased performance of the SME". The entrepreneur undoubtedly vital aspect of production (Ogunsiji \& Ladanu, 2010). The one who, according to McClelland $(1961 ; 1971)$, implements control over production, which is not simply for his consumption. Furthermore, he discovered the psychological aspect in explaining the need for achievement as the motivational factor for the entrepreneurs to execute better. Chandler \& Redlick, (1961) McClelland \& Winter, 1971) pointed out that that skills, motivational factors and incentives, personal traits, and high need for achievement as factors towards achieving entrepreneurial success. Scholars have described the term EO differently: EO has been used to describe the set of personal psychological traits, values, attributes, and attitudes strongly associated with a motivation to engage in entrepreneurial activities (McClelland 1962; Dunkelberg and Cooper 1982; Hornaday and Aboud 1971; Timmons 1978); EO is a firmlevel construct (Covin and Slevin 1991) that is closely linked to strategic management and the strategic decision-making process (Birkinshaw 1997; Burgelman 1983; Lumpkin and Dess 1996; Naman and Slevin 1993); EO is a process construct that concerns 'the processes, practices, and decision-making activities that lead to new entry' (Dess and Lumpkin 2001); Wiklund and Shepherd 2003 conceptualized EO as a firm-level strategymaking process that firms use to enact their organizational purpose, sustain their vision, and create competitive advantages. Hence, EO involves the intentions and actions of individual business owners and/or key management decision makers functioning in the complex process of making strategic choices aimed at the achievement of desired business objectives (financial and nonfinancial). Therefore, EO is not only an individual phenomenal, but also a firm-level phenomenon or construct. The firm objectives are an extension of the individual entrepreneurial man- 
ager objectives. Consequently, firm level behavior is but a refiection of the underlying business posture of the owner/manager.

A popular measure for operationalizing EO in both the entrepreneurship and the strategic management was developed by Covin and Slevin (1989), based on the earlier work of Khandwalla (1977) and Miller and Friesen (1982). This measure is known as the three dimensions of EO (3D of EO). In developing this measure, Covin and Slevin theorized that the 3D of EO - innovation, proactiveness, and risk-taking - acted together to 'comprise a basic unidimensional strategic orientation' and should be aggregated together when conducting research in the field of entrepreneurship (Covin and Slevin 1989). Drawing on the previous research, Lumpkin and Dess (1996) explained EO in five dimensions: autonomy, innovativeness, risk-taking, proactiveness, and competitive aggressiveness. These five dimensions of EO construct vary independently and firms can have different combinations of these five dimensions. Lumpkin and Dess (2001) found that the EO dimensions of proactiveness and competitive aggressiveness are only conceptually distinct, but they do not vary with each other. Each considered the internal structure of the firm and the external environment within which the firm operates; however, the representations of these factors and relationships are all different. The Covin and Slevin (1991) presents a less generic view of corporate entrepreneurship, focusing on the concept of EO defined as firm-level behavior. The key points of the external variable, strategic variables. And internal variables all have a strong effect on EO. Entrepreneurial orientation affects the three categories of variables, although weakly. EO also strongly affects firm performance, and in the reverse, firm performance has a weaker effect on EO. Another key feature of the Covin and Slevin (1991) indicates that the three categories of variables (internal, strategic, and external) have a moderating effect on the relationship between EO and productivity. This is in line with other studies (Covin and Slevin 1991; Lumpkin and Dess 1996; Miller 1983; Venkatraman 1989) on the relationship between EO and performance of SMEs. Therefore, the EO of a firm reveals itself by the evidence of how innovative is the firm, the firm's attitude to risk-taking, how proactive (i.e. alert) is it to business opportunities, and how responsive is it to trends and developments in the marketplace. Hence, the subvariables or parameters explaining the firm innovativeness are new product development, emphasis on Research and Development (R\&D), and reorganization; risk-taking is explained by proclivity for risky projects, risk-handling, and reward style. Proactiveness is described by environmental scanning, opportunity identification methods, and firms alertness to competition in the marketplace. How the firms reflect these parameters determines the firm's orientation with respect to innovativeness, risk-taking, and proactiveness, and the aggregation of these three dimensional variables explains the firm's EO. Thus, they individually and collectively affect the EO, and the EO affects the productivity.

\section{CONCLUSION AND RECOMMENDATIONS}

Entrepreneurial Orientation has a significant remedy for productivity, but the direction of the relation is not static, In situations like this if the Nigeria government wants to meet up with with 2020 where Nigeria will be one of the 20 largest economies in the world, able to consolidate its leadership role in Africa and establish itself as a significant player in the global economic and political arena. As has embarked on the journey towards vision 20-2020, where to become a high income and high productivity economy will be undeniable. Nigeria government must create conducive environment to unleash economic growth which can be done by developing the SMEs as the bedrock of growth and innovation .For Nigeria, where several 
issues as unemployment which remain (at $23.90 \%$ in 2014 ), poverty rate remain at (world bank data for poverty incidence at $46.0 \%$ in 2010$)$ growth rate at $(7.4 \%$ in 2014$)$, challenges and uncertainties at the global level (globalization, liberalization and fake and supe standize goods from countries from China, India, intensified the competition for trade and investment) and internal challenges (providing a conducive investment environment and high quality human capital) are still mingle around the corner We furthermore reflect on entrepreneurial orientation as an innovation that not only holistic but proactive in action to materialize the conception of new resources and in new ways of combining available resources for increased productivity. The entrepreneurs need to have a cognitive perspective as with the way the entrepreneurs think and how they arrive at decisions, thus lead to the entrepreneurial orientation of the SMEs and ultimately lead to increased productivity.

\section{References}

[1] Amao, J.O. (1997). -Modes of Financing Small Scale Industries in B.U.N\|l Igwe et al (eds.). =Proceedings of the Conference on Small-Scale Industries and the Development of Nigeriall. NISER, Ibadan, March, PP. 360-394

[2] Birkinshaw, J. 1997. "Entrepreneurship in Multinational Corporation: The Characteristics of Subsidiary Initiatives.” Strategic Management Journal 18 (3): 207-229.

[3] Brown, T. E., and B. A. Kirchhoff. 1997. "The Effects of Resource Availability and Entrepreneurial Orientation on Firm Growth." In Frontiers of Entrepreneurship Research, edited by P. D. Reynolds, W. D. Bygrave, N. Carter, P. Davidsson, W. B. Gartner, and P. P. McDougall. Wellesley, MA: Babson College.

[4] Burgelman, R. A. 1983. "Corporate Entrepreneurship and Strategic Management: Insights from a Process Study." Management Science 29: 1349-1364.

[5] Covin, J. G., and D. P. Slevin. 1991. "A Conceptual Model of Entrepreneurship as Firm Behavior." Entrepreneurship Theory and Practice (Fall): 7-25.

[6] Covin, J. G., \& Slevin, D. P. (1989). Strategic Management of Small Firms in Hostile and Benign Environment. Strategic Management Journal, 10 (1), 75 - 87.

[7] Covin, J.G, \& Adler, P (1989). Strategic behavior, strategy pattens and performance levels of small entrepreneurial and conservative firms. Southern Management Assocation Proceeding, 250-252

[8] Central Bank of Nigeria(CBN)(2007), Economic Report for the Second Quarter of 2007

[9] http://data.worldbank.org/country/nigeria downloaded at $5.50 \mathrm{pm}$ December 2014

[10] http://www.tradingeconomics.com/nigeria/unemployment-rate downloaded at $5.00 \mathrm{pm}$ December 2014

[11]Dess, G. G., and G. T. Lumpkin. (2001) "Emerging Issues in Strategy Process Research." In The Blackwell Handbook of Strategic Management, edited by M. A. Hitt, R. E. Freeman, and J. S. Harrison, 3-4. Malden, MA: Blackwell Publishers.

[12]Dunkelberg, W. C., and A. C. Cooper. (1982). "Entrepreneurial Typologies." In Frontiers of Entrepreneurship Research, edited by K. H. Vesper, 1-15. Wellesley, MA: Babson Centre for Entrepreneurial Studies. 
[13]Fairoz, F. M. (2010). Entrepreneurial Orientation and Business Performance of Small and Medium Scale Enterprises of Hambantota District, Sri Lanka. Asian Social Science, 6(3), $34-46$.

[14]Ferreira, Jo ao, and S. G. Susana Azevedo. (2007). "The Impact of Entrepreneurial Orientation and Resource-Based View on Growth of Small Firms." Paper presented at the 30th Conference of the Institute of Small Business and Entrepreneurship, Glasgow, Scotland, November 7-9.

[15]Hart, S. 1992. “An Integrative Framework for Strategy-Making Process.” Academy of Management Journal 17: 327-351.

[16]Hurst, E., \& B. W. Pugsley. (2011). What do small businesses so? Brookings Papers on Economic Activity, 2011(2) (Fall), 73-118. http://dx.doi.org/10.1353/eca.2011.0017

[17]Hoq, M. Z., Ha, N. C., \& Said, S. M. (2009). SMEs in the Malaysian Economy. International Journal of Marketing Studies, 1(2), 3-17.

[18]Hornaday, J. A., and J. Aboud.( 1971). "Characteristics of Successful Entrepreneurs", Personnel Psychology 24: 141-153.

[19] McClelland, D. (1987). Characteristics of Successful Entrepreneurs. Journal of Creative Behaviour, 21(3), 219-233.

[20]McClelland, D. C. 1962. "Business Drive and National Achievement." Harvard Business Review (July-August): 99-112.

[21] Miller, D (1983). The correlates of entrepreneurship in three types of firms. Management sciences, $29770-791$

[22] Miller, D., \& Friesen, P. H. (1982). Innovation in conservative and entrepreneurial firms: two models of strategic momentum. Strategic Management Journal 3(1), 1-25.

[23] Madsen, E. L. (2007). The significance of sustained entrepreneurial orientation on performance of firms - A longitudinal analysis. Entrepreneurship and Regional Development, 19(2), 185-204

[24] Mohd Aris, N. (2006). SMEs: Building Blocks for Economic Growth. Paper presented at the The National Statistics Conference .

[25] Mohd Asri, A., \& Mohd. Isa, B. (2000). Small and Medium Enterprises in Asian Pacific Countries: Development prospects.

[26] Naman, J. L., and D.P. Slevin. 1993. "Entrepreneurship and Concept of Fit: A Model and Empirical Tests.” Strategic Management Journal 14: 137-153.

[27] Surienty, L., Hong, K. T., \& Hung, D. K. M. (Producer). (2011, 20/2/2011) Occupational Safety and Health (OSH) in SMEs in Malaysia: A Preliminary Investigation.

[28] Survey Report on MSMEs in Nigeria. Retrieved 18/12/2014, page 25 by 6:44 pm.

[29] Timmons, J. A. (1978) "Characteristics and Role Demand of Entrepreneurship." American Journal of Small Business 3: 5-17. 
[30]Rauch, A., J. Wiklund, M. Frese, and G. T. Lumpkin. (2004). "Entrepreneurial Orientation and Business Performance: Cumulative Empirical Evidence." In Frontiers of Entrepreneurship Research 2004. Proceedings of the Twenty-Fourth Annual Entrepreneurship Research Conference, edited by S. A. Zahra et al., 164-177. Braintree: P and R Publications.

[31]Lumpkin, G. T., and G. G. Dess. (2001). "Linking Two Dimensions of Entrepreneurial Orientation to Firm Performance: The Moderating Role of Environment and Industry Life Cycle." Journal of Business Venturing 16: 429=451.

[32]Lewis, W.A. (1997). -Reflections on the Structure of Nigerian Manufacturing Industryll in O. Teriba and M.O. Kayode (eds.). Industrial Development in Nigeria: Patterns, Problems and Prospects. Ibadan University Press, P. 337

[33] Giwa, R. (May, 2001). -How to Revive Nigeria‘s Ailing Industrial Sectorll. The Guardian.

[34] Oshagbemi, T.A. (1982). Small Business Management in Nigeria. Longman, London. P.3

[35] Ogun, O. and Anyanwu, J.C. (1999). -Financing Small and Medium Enterprises in Nigeria: Lessons from International Experiences. The Nigerian Financial Review. Vol. 8, No. 1, March, P.12.

[36] Ogunsiji, P. A. S., \& Ladanu, W. K. (2010). Entrepreneurial Orientation as a Panacea for the Ebbing Productivity in Nigerian Small and Medium Enterprises: A Theoretical Perspective. International Business Research, 3(4), 192 -199.

[37] Wiklund, J., and D. Shepherd. 2003. "Knowledge-Based Resources, Entrepreneurial Orientation, and the Performance of Small and Medium-sized Businesses." Strategic Management Journal 24: 1307-1314. 